\title{
Do roadkill aggregations of wild and domestic mammals overlap?
}

\author{
Carine Firmino Carvalho-Roel ${ }^{1}$, Ana Elizabeth Iannini-Custódio ${ }^{2}$ \& Oswaldo Marçal Júnior ${ }^{1,2}$ \\ 1. Post-Graduate Program in Ecology and Conservation of Natural Resources, Federal University of Uberlândia, \\ Uberlândia, MG, Brazil, 1720 Pará Avenue, Uberlândia, Brazil; carinefcarvalho@gmail.com \\ 2. Biology Institute, Federal University of Uberlândia, Uberlândia, MG, Brazil, 1720 Pará Avenue, Uberlândia, Brazil; \\ iannini.custodio@gmail.com,omarcaljr@gmail.com
}

Received 17-IV-2018. C Corrected 30-VII-2018. Accepted 21-I-2019.

\begin{abstract}
Domestic animals are involved in a large number of traffic accidents and they represent danger to humans due to their size. Despite this, few studies consider domestic animals. That is why we evaluate mammals' roadkill aggregations in order to locate them and to determine if wild and domestic mammals' roadkills overlap. In addition, we investigate the influence of the landscape on the location of the aggregations. This study was carried out on the BR-050 highway, an area of Cerrado biome, in Southeastern Brazil. The monitoring was executed from April 2012 to March 2013, by car, at an average speed of $60 \mathrm{~km} / \mathrm{h}$, with two observers looking for roadkills on the highway. We found 482 mammals' roadkills, including 260 (54\%) wild mammals, $164(34 \%)$ domestic and $58(12.0 \%)$ undetermined specimens. Of the 21 recorded mammal species, five were domestic. The wild mammals' roadkill rate was $0.03( \pm 0.02)$ individuals $/ \mathrm{km} /$ day and the domestic roadkill rate was $0.02( \pm 0.01)$. We detected roadkill aggregations for wild and domestic mammals. Roadkill hotspots of domestic mammals and wild mammals did not overlap. The variables that had the highest influence on wild mammals' roadkill probability were: agriculture and silviculture cover as positive effects and distance to the nearest river, to the urban perimeter and to a natural fragment as negative effects. For domestic mammals these variables were: area of the smallest fragment and distance to a natural fragment as positive effects and silviculture cover as a negative effect. The explanation for the wild and domestic mammals' roadkill hotspot non overlapping seems to be the effect of each variable in determining the roadkill hotspot since their effect is different for wild and domestic mammals. On the other hand, this non overlapping can be a result of domestic mammals' scavenging habits. We propose different kinds of mitigation measures in order to reduce domestic and wild mammals' roadkill.
\end{abstract}

Key words: road ecology; wildlife vehicle collision; roadkill hotspot; road mortality; spatial patterns; Cerrado; South America.

Carvalho-Roel, C. F., Iannini-Custódio, A. E., \& Marçal Júnior, O. (2019). Do roadkill aggregations of wild and domestic mammals overlap? Revista de Biología Tropical, 67(1), $47-60$.

One objective of roadkill surveys is the reduction of traffic accidents caused by collisions with wildlife, increasing safety for road users and preserving the biodiversity (Van der Ree, Smith, \& Grilo, 2015). In the United States, material damage from collisions of this nature is estimated to exceed $\$ 1$ billion and 1500 people have died in such accidents over the past 10 years (Grilo, Bissonette, \& Cramer, 2010). One million animals die each day from fatal accidents with vehicles in that same country (Forman, 1998). In this way, wildlife roadkill is one of the negative effects caused by roads that have been more widely 
studied (Forman \& Alexander, 1998; Trombulak \& Frissell, 2000; Coffin, 2007; Laurance, Goosem, \& Laurance, 2009; Van der Ree et al., 2015).

In Brazil, the most conservative rate points to 14.7 ( \pm 44.8) million animals being killed in a car accident every year (Dornas, Kindel, Bager, \& Freitas, 2012), while another research indicates a rate as big as 475 million animals/ year (Centro Brasileiro de Ecologia de Estradas, 2017). These data indicate the urgency of studies addressing this issue, in order to reduce the loss of biodiversity and public expenditures (Bager, Piedras, Martin, \& Hóbus, 2007). Nevertheless, studies focusing on wildlife roadkill aggregation are recent in this country (Coelho, Kindel, \& Coelho, 2008; Esperandio, 2011; Bueno, Freitas, Coutinho, Oswaldo Cruz, \& Castro Júnior, 2012; Santana, 2012; Teixeira et al., 2013; Ferreira, Ribas, Casella, \& Mendes, 2014; Carvalho, Iannini Custodio, \& Marçal Junior, 2015; Ascensão, Desbiez, Medici, \& Bager, 2017; Santos et al., 2017). Although it is not a focus of wildlife roadkill monitoring, domestic animals are also being killed on roads and because of their size, they can pose a threat to human safety. The studies that evaluate the domestic mammals' roadkill hotspots (Esperandio, 2011) or that do at least a survey of the domestic fauna roadkill are rare (Bagatini, 2006; Freitas, 2009; Esperandio, 2011; Omena Junior, Pantoja-Lima, Santos, Ribeiro, \& Aride, 2012).

It is essential to look for possible patterns of roadkill distribution, including domestic animals since these are responsible for a substantial amount of collisions (Esperandio, 2011). Roadkill aggregation zones, called hotspots, have been determined for several groups of wild animals, indicating that roadkill is usually not random (Clevenger, Chruszcz, \& Gunson, 2003; Malo, Suárez, \& Díez, 2004; Teixeira et al., 2013; Santos et al., 2017;) and hotspots can vary in time and space (Santos et al., 2017; Gonçalves et al., 2018). However, for domestic mammals the question still remains, is domestic mammals' roadkill aggregated? Knowing where and when roadkill happens more frequently, enables one to identify critical points for the implementation of mitigation measures, such as fauna passages, fences, warning signs and electronic barriers (Glista, DeVault, \& DeWoody, 2009; Grilo et al., 2010; Lesbarrères \& Fahrig, 2012)

For domestic mammals, the occurrence of hotspots is probably different from those found for wild species, since the presence of domestic animals on the highways is due to very particular factors (Esperandio, 2011), human presence or abandonment being the most important. On the other hand, domestic and wild mammals' roadkill could overlap because some domestic mammals act as scavengers and could be killed in the same sites as those of wild mammals (Slater, 2002; Schwartz, Williams, Chadwick, Thomas, \& Perkins, 2018). Therefore, if hotspots of domestic animals overlap with those of wild species, they could be used to plan mitigation measures for a broad spectrum of species as proposed by Teixeira et al. (2013) for wild animals. In this context, the present study was undertaken to evaluate mammal roadkill aggregations in a Cerrado area, to locate these hotspots, to determine if wild and domestic mammal roadkill overlap and to explain through landscape analysis why these hotspots overlap or not.

\section{MATERIAL AND METHODS}

Study Site: The survey was carried out on the stretch of the highway BR-050 between Uberlândia and Uberaba, Minas Gerais State, Brazil (Uberlândia, 1854'46.19”' S \& 48 13 '24.54" W; Uberaba, 1943'59.29” S \& $47^{\circ} 58^{\prime} 56.68^{\prime \prime}$ W) (Fig. 1). The climate of the region presents seasonality, the rainy summer is from October to April and the dry winter from May to September (Rosa, Lima, \& Assunção, 1991). The study area is in the Cerrado biome, which has campos, forest formations, gallery forest and veredas (Araújo \& Haridasan, 1997). On the other hand, the intense agricultural activity reduced the Cerrado to small and isolated fragments (Araújo, Nunes, Rosa, \& Resende, 1997). In this section of the BR-050, 


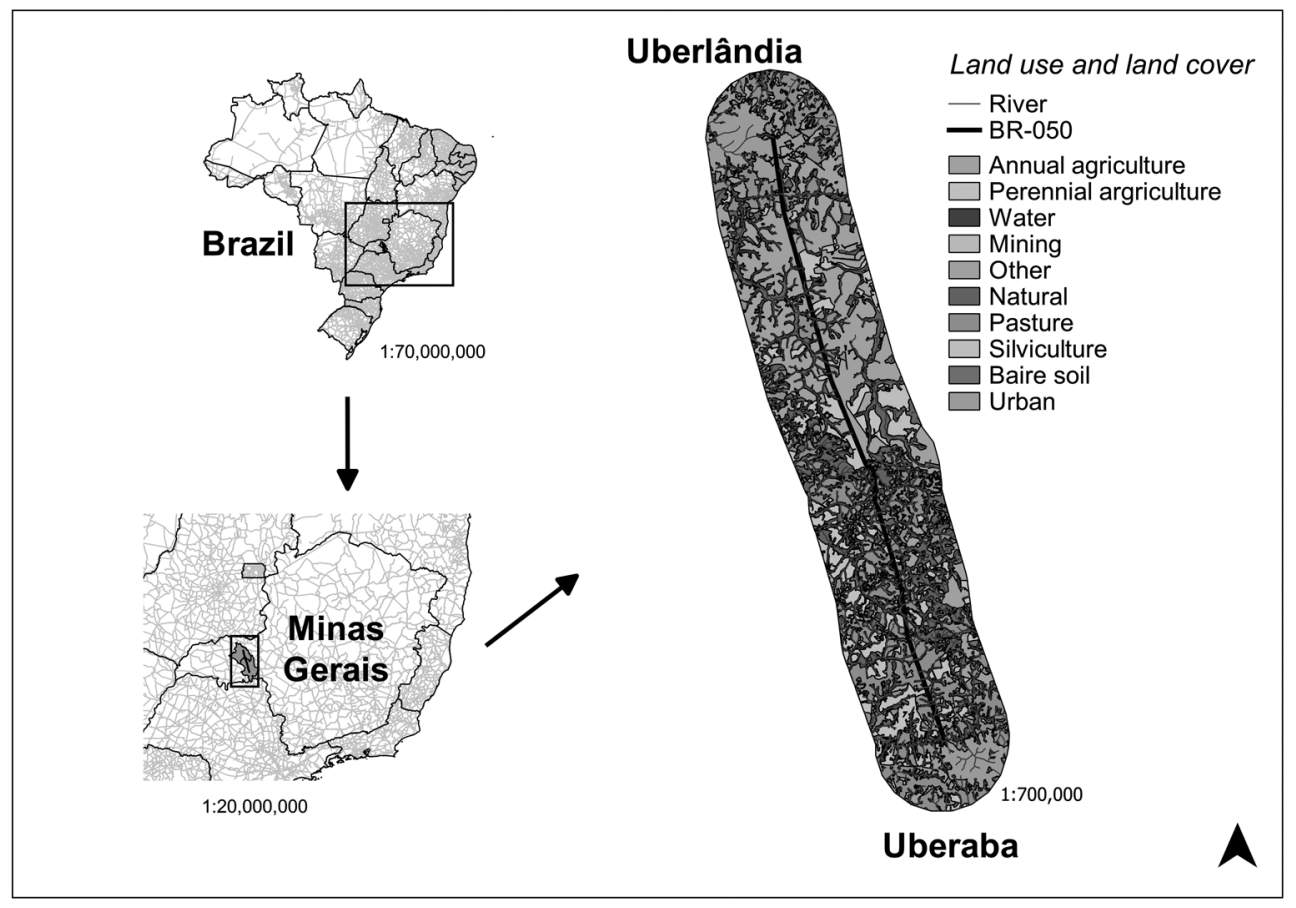

Fig. 1. Study area highlighting land use and land cover in a $10 \mathrm{~km}$ buffer around the BR-050 highway, Uberlândia-Uberada, Minas Gerais state, Brazil (2012-2013).

the highway crosses the rivers Uberaba and Uberabinha, some streams and several veredas or palm swamps. This highway is approximately $96 \mathrm{~km}$ and is a paved four-lane road. The road has hard shoulders and median strips. In April 2015, around 218839 vehicles passed through the BR-050 highway (Concessionária de rodovias Minas Gerais Goiás S/A, 2018).

Procedures: The road was monitored weekly, from April 2012 to March 2013, by car, at an average speed of $60 \mathrm{~km} / \mathrm{h}$, with two observers looking for roadkills on the highway. The monitoring trip started at 07:30 in the morning and lasted for the time necessary to cover the entire stretch. As the highway is a four-lane road, being the opposite lanes separated by a median strip, it was monitored in both directions (from Uberlândia to Uberaba, and from Uberaba to Uberlândia), totaling 192 $\mathrm{km}$ traveled weekly, 42 trips and $8064 \mathrm{~km}$ at the end of one year of data collection, representing a sampling effort of $22.1 \mathrm{~km} /$ day.
After registration, we removed the carcass from the highway to avoid further recounts. Mammals' roadkill identification was carried out based on Reis, Peracchi, Fragonezi, \& Rossaneis (2010). We also consulted specialists to confirm these identifications. We only included in the analysis those animals whose identification allowed for grouping them safely in wild or domestic categories.

In order to get data from the landscape, we used a map of land use and land cover produced by the Ministry of the Environment, with a 1:250000 scale and made based on satellite images from 2013 (Ministério do Meio Ambiente, 2015). We split the highway into 96 segments of $1 \mathrm{~km}$ each and created a buffer of this same size around each segment. Then, we quantified the area in this buffer for each one of these categories: agriculture, pasture, silviculture and natural cover. For each segment, we also calculated the distance to the nearest river (D_river), to the urban perimeter (D_urban) and to the nearest fragment of natural cover 
(D_fragment). Finally, we reckoned the number of fragments (N_fragments), the area of the smallest and largest natural fragment (S_fragment, L_fragment) and the presence of a river (River_presence) within the buffer area for each segment.

Data analyses: The 2D Ripley's K-Statistics test from Siriema v1.1 software tests the existence or not of roadkill aggregations in different scales (Coelho, Coelho, Kindel, \& Teixeira, 2011). The function L(r) used for the interpretation of the test results allows for evaluating the intensity of aggregation in different scales. An initial radius of 100 $\mathrm{m}$, a radius increase of $500 \mathrm{~m}$, a confidence level of $95 \%$ and 1000 simulations were used (modified from Coelho et al., 2011; Cáceres, Casella, \& Goulart, 2012; Teixeira et al., 2013). The values of initial radius and radius increment corresponded to the scale at which mitigation measures could be effective (Teixeira et al., 2013).

We used the 2D HotSpot Identification test to identify where the roadkill aggregations were localized (Coelho et al., 2011). The $\mathrm{N}_{\text {events }}$
- $\mathrm{N}_{\text {simulated }}$ function used to interpret the test results allows to assess at what locations on the highway roadkill aggregations were located. We used a radius of $500 \mathrm{~m}$ because the lower the range of analysis, the more detailed the results are, scale in which the roadkill aggregations were significant, according to the results of the 2D Ripley K-Statistics test. A confidence level of $95 \%$ and 1000 simulations were used. Uberlândia city was the $\mathrm{km}$ zero and Uberaba city the $\mathrm{km} 96$.

In order to compare if the roadkill hotspots' location were similar between the different groups, we used the same procedure that Teixeira et al. (2013) used. The sections of the highway were considered sample units, the Siriema program calculates an aggregation index for each section of the highway (500 sections of $192 \mathrm{~m}$ each) (Coelho et al., 2011). We transformed the aggregation intensity data into binary variables representing the roadkill hotspots presence/absence (Teixeira et al., 2013; Santos et al., 2017). We corrected wild and domestic mammals aggregations position by \pm 1 and $2 \mathrm{~km}$. Than we performed a phi correlation in order to assess the similarity of wild

TABLE 1

Variance Inflation Factors (VIF) for land use and land cover independent variables, BR-050 highway, Uberlândia-Uberaba, Minas Gerais state, Brazil (2012-2013)

\begin{tabular}{lccc}
\multicolumn{1}{c}{ Variables } & VIF - without exclusion & VIF - 1 exclusion & VIF - 2 exclusions \\
Agriculture & 21.84476 & 6.340877 & 4.047764 \\
D_fragment & 8.807212 & 8.466067 & 6.149074 \\
D_river & 2.855073 & 2.450321 & 4.238801 \\
D_urban & 3.338178 & 3.322098 & 2.706591 \\
L_fragment & 14.32365 & 12.90922 & excluded \\
N_fragments & 7.529584 & 7.269773 & 4.273296 \\
Natural & 23.52738 & 22.57528 & 4.644611 \\
Pasture & 14.91319 & excluded & excluded \\
River_presence & 1 & 1 & 1 \\
S_fragment & 2.732065 & 2.738433 & 3.020286 \\
Silviculture & 3.533716 & 1.859377 & 3.079449 \\
\hline
\end{tabular}

In the second column, VIF was calculated for all land use and land cover independent variables. In the third column, VIF was calculated after excluding the variable Pasture (based on its relation to the answer variables in Appendix 1 and Appendix 2). In the fourth column, VIF was calculated after excluding the variables Pasture and L_fragment (the maintenance of the variable Natural instead of L_fragment was an ecological choice). We considered an acceptable VIF $<10$ (Montgomery \& Peck, 1992). 
and domestic mammals hotspots location using sjstats package (Lüdecke, 2018) in R 3.4.1 program (R Core Team, 2018).

In order to understand what kind and how land use influences roadkill hotspots, we created GLM models. First, we investigated multicollinearity among predictors using the Variance Inflation Factors (VIF) from the package car (John \& Weisberg, 2011) (Table 1). We excluded variables Pasture and $\mathrm{L}$ fragment that had a VIF > 10 (Montgomery \& Peck, 1992) and that were less correlated to the response variables (Appendix 1 and Appendix 2). The response variable was the presence/absence of roadkill hotspot in each segment (we used a binomial distribution and a logit link function). We ran GLM analyses using GLmulti package in $\mathrm{R}$ (Calcagno, 2015) and set a maximum of four variables per model in order to facilitate models' interpretation. Model selection was performed using the Akaike Information Criterion for small samples (AICc), retaining all models within $\triangle \mathrm{AICc}<2$. We calculated $\mathrm{AICc}$ weights (wAICc) to compare the relative support of each model. The Area Under Cover (AUC) was calculated using epiDisplay package (Chongsuvivatwong, 2018). The Relative Importance Weight (RIW) was reckoned for the variables to understand the importance of each one using package GLmulti (Calcagno, 2015) (RIW > 0.9, strong effect; 0.9-0.6, moderate; 0.6-0.5, weak). We ran these tests in $\mathrm{R} 3.4 .1$ program (R Core Team, 2018).

\section{RESULTS}

We found 482 mammals' roadkill, including $260(54 \%)$ wild mammals, 164 (34\%) domestic animals and 58 (12\%) were not possible to determine if they were wild specimens or not. Of the 21 recorded mammal species, five were domestic/exotic. The wild species most killed were: Cerdocyon thous, Euphractus sexcinctus and Conepatus semistriatus; the domestic ones were: Canis familiaris and Felis catus (Table 2).

The wild mammals' roadkill rate was $0.03( \pm 0.02)$ individuals $/ \mathrm{km} / \mathrm{day}$, with at least

TABLE 2

Mammals' roadkill on BR-050 highway, Uberlândia-Uberaba, Minas Gerais state, Brazil (2012-2013)

\begin{tabular}{|c|c|c|c|}
\hline Taxa & $\mathrm{N}$ & $\mathrm{C} \%{ }^{1}$ & Roadkill rate ${ }^{2}$ \\
\hline Mammalia (non identified species) & 43 & 8.9 & 0.53 \\
\hline \multicolumn{4}{|l|}{ Didelphimorphia } \\
\hline \multicolumn{4}{|l|}{ Didelphidae } \\
\hline Didelphis albiventris Lund, 1840 & 7 & 1.5 & 0.08 \\
\hline Lutreolina crassicaudata (Desmarest, 1804) & 2 & 0.4 & 0.02 \\
\hline \multicolumn{4}{|l|}{ Pilosa } \\
\hline Myrmecophagidae (non identified species) & 1 & 0.2 & 0.01 \\
\hline Myrmecophaga tridactyla Linnaeus, 1758 & 3 & 0.6 & 0.03 \\
\hline Tamandua tetradactyla (Linnaeus, 1758) & 14 & 2.9 & 0.17 \\
\hline \multicolumn{4}{|l|}{ Cingulata } \\
\hline Dasypodidae (non identified species) & 15 & 3.1 & 0.18 \\
\hline Cabassous sp. McMurtie, 1831 & 3 & 0.6 & 0.03 \\
\hline Dasypus novemcinctus Linnaeus, 1758 & 10 & 2.1 & 0.12 \\
\hline Dasypus sp. Linnaeus, 1758 & 5 & 1.0 & 0.06 \\
\hline Euphractus sexcinctus (Linnaeus, 1758) & 44 & 9.1 & 0.54 \\
\hline \multicolumn{4}{|l|}{ Perissodactyla } \\
\hline \multicolumn{4}{|l|}{ Equidae } \\
\hline Equus caballus Linnaeus, $1758 *$ & 1 & 0.2 & 0.01 \\
\hline \multicolumn{4}{|l|}{ Artiodactyla } \\
\hline \multicolumn{4}{|l|}{ Suidae } \\
\hline Sus domesticus Erxleben, 1777 * & 1 & 0.2 & 0.01 \\
\hline Primates & & & \\
\hline
\end{tabular}


TABLE 2 (Continued)

\begin{tabular}{|c|c|c|c|}
\hline Taxa & $\mathrm{N}$ & $\mathrm{C} \%{ }^{1}$ & Roadkill rate ${ }^{2}$ \\
\hline \multicolumn{4}{|l|}{ Cebidae } \\
\hline Callithrix penicillata (É. Geoffroy, 1812) & 3 & 0.6 & 0.03 \\
\hline Carnivora (non identified species) & 1 & 0.2 & 0.01 \\
\hline Canidae (non identified species) & 10 & 2.1 & 0.12 \\
\hline Canis familiaris Linnaeus, $1758 *$ & 100 & 20.7 & 1.24 \\
\hline Cerdocyon thous (Linnaeus, 1758) & 52 & 10.4 & 0.64 \\
\hline Chrysocyon brachyurus (Illiger, 1815) & 8 & 1.7 & 0.09 \\
\hline Lycalopex vetulus (Lunda, 1842) & 8 & 1.7 & 0.09 \\
\hline \multicolumn{4}{|l|}{ Felidae } \\
\hline Felis catus Linnaeus, $1758 *$ & 61 & 12.7 & 0.75 \\
\hline Leopardus pardalis (Linnaeus, 1758) & 1 & 0.2 & 0.01 \\
\hline Leopardus sp. Gray, 1842 & 1 & 0.2 & 0.01 \\
\hline \multicolumn{4}{|l|}{ Mephitidae } \\
\hline Conepatus semistriatus (Boddaert, 1785) & 43 & 8.9 & 0.53 \\
\hline \multicolumn{4}{|l|}{ Mustelidae } \\
\hline Galictis cuja (Molina, 1782) & 4 & 0.8 & 0.04 \\
\hline \multicolumn{4}{|l|}{ Procyonidae } \\
\hline $\begin{array}{l}\text { Procyon cancrivorus } \\
\text { (Cuvier, 1798) }\end{array}$ & 20 & 4.1 & 0.24 \\
\hline \multicolumn{4}{|l|}{ Lagomorpha } \\
\hline \multicolumn{4}{|l|}{ Leporidae } \\
\hline Lepus europaeus Pallas, 1778 * & 1 & 0.2 & 0.01 \\
\hline Rodentia (non identified species) & 4 & 0.8 & 0.04 \\
\hline \multicolumn{4}{|l|}{ Caviidae } \\
\hline Hydrochoerus hydrochaeris (Linnaeus, 1766) & 13 & 2.7 & 0.16 \\
\hline \multicolumn{4}{|l|}{ Erethizontidae } \\
\hline Coendou prehensilis (Linnaeus, 1758) & 3 & 0.6 & 0.03 \\
\hline
\end{tabular}

1. Percentage given by the relation of the total number of individuals of each taxon and the total number of mammals.

2. Roadkill rate - individuals/km/day*100.

* Domestic/exotic mammals.

two animals per day, at most 17 , and an average $6.26( \pm 3.47)$ wild animals. The monthly roadkill rate was $0.98( \pm 0.54)$ individuals/ $\mathrm{km} /$ month. The annual roadkill rate was 11.90 $( \pm 6.60)$ individuals $/ \mathrm{km} /$ year. The domestic mammals' roadkill rate was $0.02( \pm 0.01)$ individuals $/ \mathrm{km} /$ day, with at least one animal being found per day, at most 11 and an average $3.71( \pm 2.20)$ domestic mammals. The monthly roadkill rate was $0.61( \pm 0.33)$ individuals/ $\mathrm{km} / \mathrm{month}$. The annual roadkill rate was 7.42 $( \pm 4.17)$ individuals $/ \mathrm{km} /$ year.

Wild and domestic mammals showed roadkill aggregation (Fig. 2). The roadkill aggregations of wild mammals were located at $\mathrm{km}: 15,17,20$ to $23,25,47,86,90$ to 91 ; with greater intensity at $\mathrm{km} 23$ and 91 (Fig. 3). The hotspots of domestic mammals were located at $\mathrm{km}: 2,5$ to $6,37,39$ to 40,44 to 45,50 to 51 , 69 to $71,79,93$ to 95 ; with greater intensity at $\mathrm{km} 44$ to 45,50 to 51 and 70 (Fig. 3). The roadkill hotspots of domestic mammals and wild mammals did not overlap $\left(\mathrm{r}_{\mathrm{phi}}=-0.06 \mathrm{P}=\right.$ 0.40 ), not even when we adjusted their location for one more $\mathrm{km}\left(\mathrm{r}_{\mathrm{phi}}=0.15, \mathrm{P}<0.001\right)$, neither for two $\left(r_{\text {phi }}=0.24, \mathrm{P}<0.001\right)$ (Fig. 4). From eleven wild mammal hotspots, just two (km 47 and 91) are within two km from a domestic mammal hotspot.

Landscape models are excellent at explaining wild mammals' hotspots, while for domestic mammals they are moderately good (Table $3)$. Wild mammals' hotspots occur in larger agriculture and silviculture cover areas; near a river, a natural fragment and the urban perimeter (Table 4). Domestic mammals' hotspots 

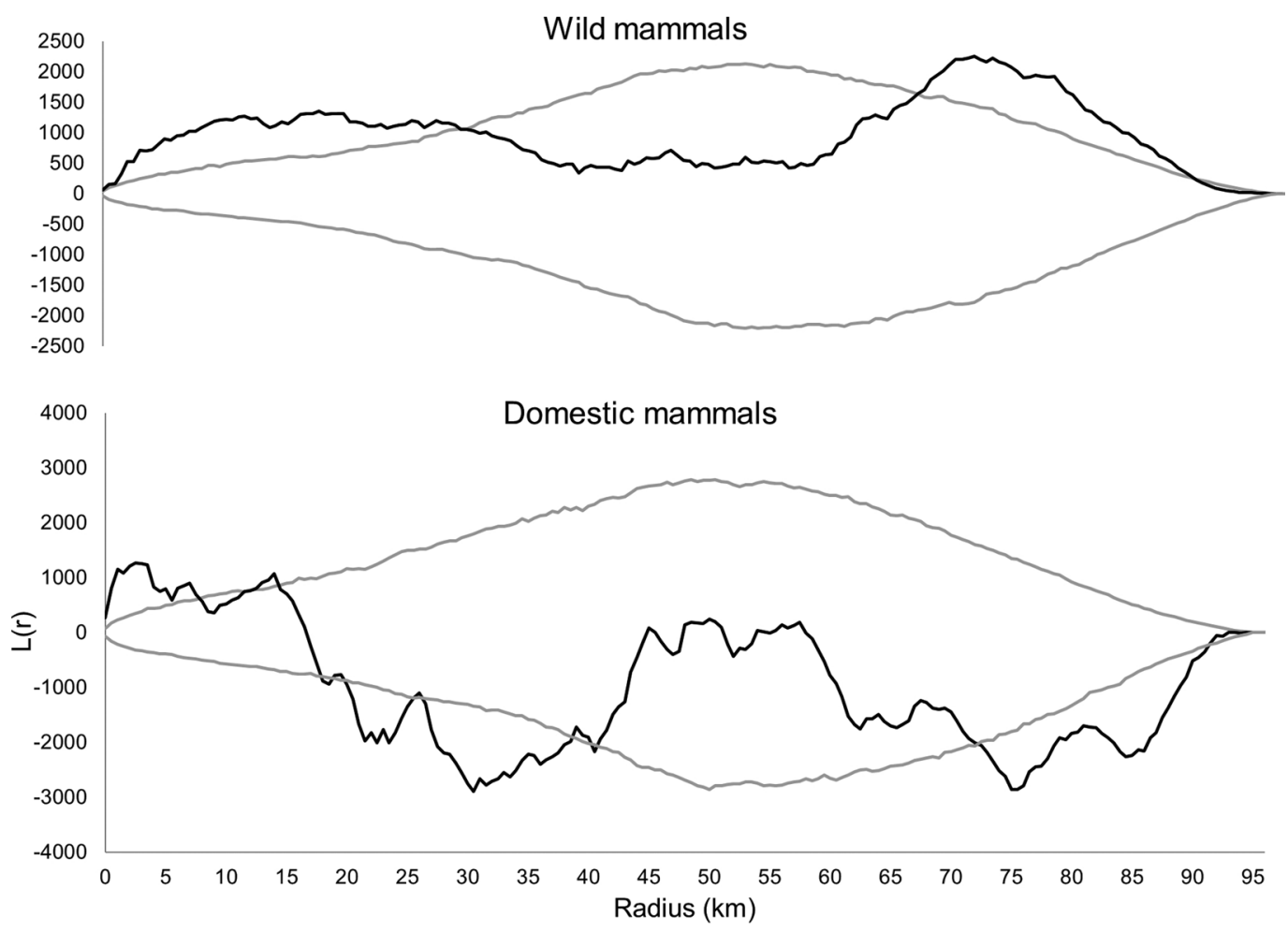

Fig. 2. Radius at which there is roadkill aggregation for wild and domestic mammals on the BR-050 highway, UberlândiaUberaba, Minas Gerais state, Brazil (2012-2013). Results from the test 2D Ripley’s K-Statistics. Black line - L(r) function, gray lines - upper and lower confidence limits, when the black line is above the gray line it means that in that radius of analysis there are roadkill aggregations.

TABLE 3

Models that best explain hotspots location selected by AICc, BR-050 highway,

Uberlândia-Uberaba, Minas Gerais state, Brazil

\begin{tabular}{|c|c|c|c|c|}
\hline Model & $\mathrm{AICc}$ & $\triangle \mathrm{AICc}$ & weight & AUC \\
\hline \multicolumn{5}{|l|}{ Wild mammals } \\
\hline Null & 70.39 & 20.62 & & \\
\hline+ Agriculture + Silviculture - D_river - D_urban & 49.77 & 0.00 & 0.40 & 0.93 \\
\hline + Agriculture + Silviculture - D_urban - D_fragment & 50.14 & 0.37 & 0.33 & 0.92 \\
\hline \multicolumn{5}{|l|}{ Domestic mammals } \\
\hline Null & 91.70 & 4.25 & & \\
\hline - Silviculture + S_fragment + D_fragment & 87.45 & 0.00 & 0.05 & 0.75 \\
\hline - Silviculture - River_presence + S_fragment & 88.38 & 0.93 & 0.03 & 0.73 \\
\hline - Silviculture & 89.03 & 1.58 & 0.02 & 0.57 \\
\hline - Silviculture + D_fragment & 89.11 & 1.66 & 0.02 & 0.65 \\
\hline - Silviculture $+\mathrm{S}$ _fragment $+\mathrm{N}$ _fragments $+\mathrm{D}$ _fragment & 89.14 & 1.69 & 0.02 & 0.76 \\
\hline - Silviculture - River_presence + S_fragment + D_fragment & 89.21 & 1.76 & 0.02 & 0.76 \\
\hline - Silviculture - River_presence & 89.21 & 1.76 & 0.02 & 0.64 \\
\hline - Silviculture + D_river $+S$ _fragment & 89.23 & 1.78 & 0.02 & 0.72 \\
\hline
\end{tabular}

$\mathrm{AICc}=$ Akaike Information Criterion for small samples; $\triangle \mathrm{AICc}=$ difference between the AICc of a given model and that of the best model; $\mathrm{AUC}=$ Area under cover. 

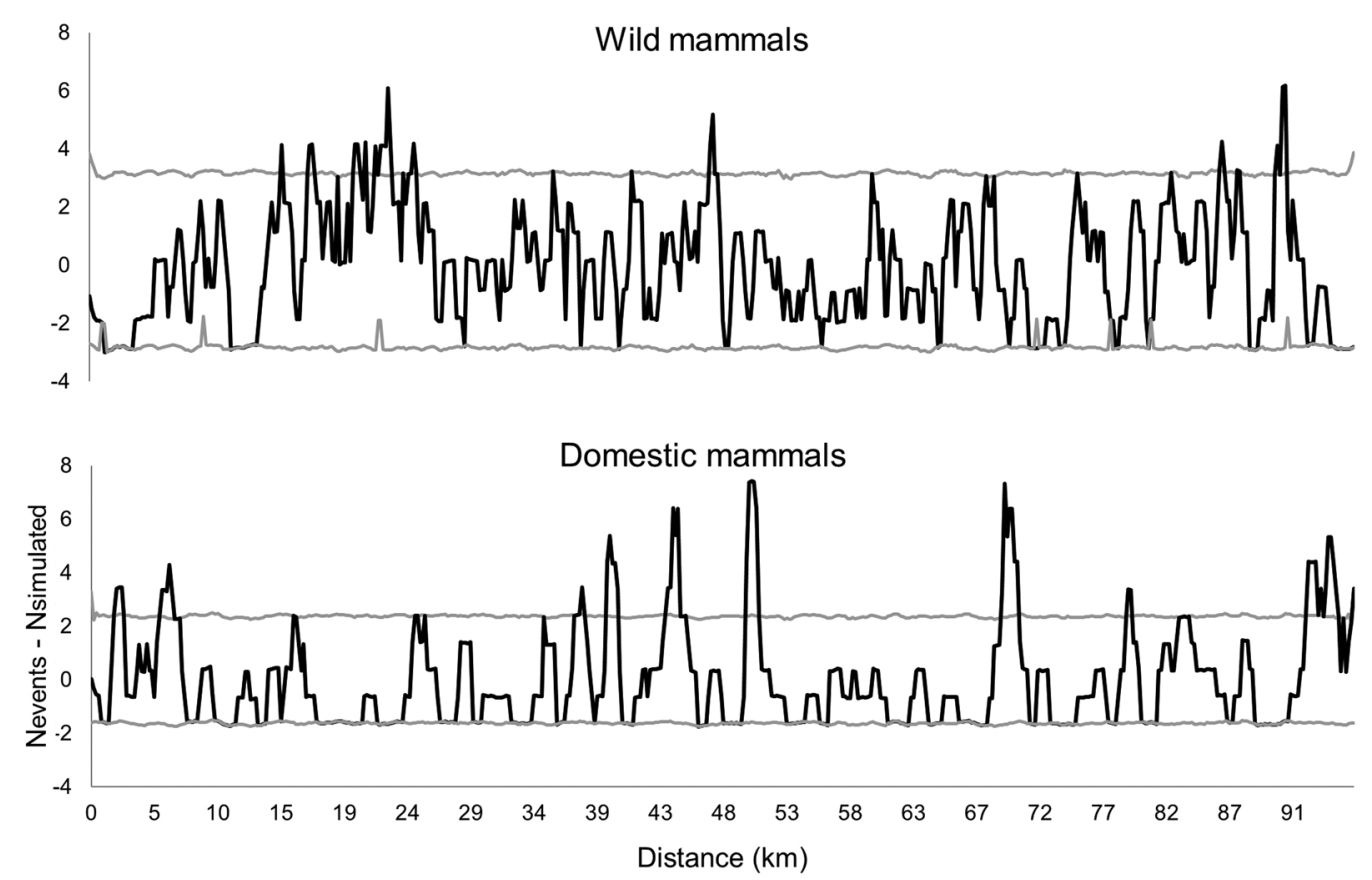

Fig. 3. Location of wild and domestic mammals' roadkill aggregations on BR-050 highway, Uberlândia-Uberada, Minas Gerais state, Brazil (2012-2013). Results from test 2D Hotspot Identification. Black line - The Nevents - Nsimulated funcion, gray lines - upper and lower confidence limits, when the black line is above the gray line it means that in that section of the highway there are roadkill aggregations.

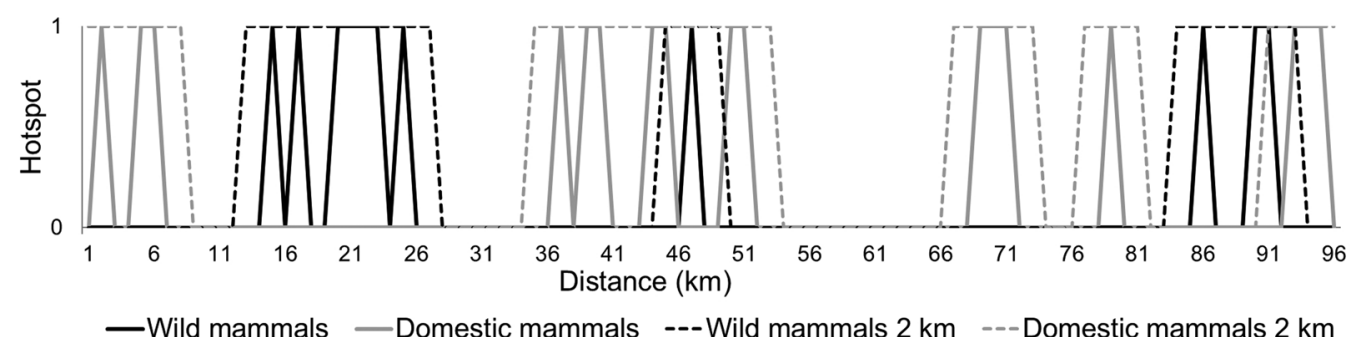

Fig. 4. Comparison of the roadkill hotspots location for wild and domestic mammals on the BR-050 highway, UberlândiaUberada, Minas Gerais state, Brazil (2012-2013). We created a correction factor of \pm two km around each hotspot for wild mammals (Wild mammals $2 \mathrm{~km}$ on the graph) and for domestic mammals (Domestic mammals $2 \mathrm{~km}$ on the graph).

are localized near smaller silviculture areas, bigger natural fragments, far from a river and in more fragmented landscapes. The difference in the location of the wild and domestic mammals' hotspots are associated with the effect of each variable, if the effect is negative for wild mammals, it is positive for domestic mammals and vice versa.

\section{DISCUSSION}

The present study showed that nearly $30 \%$ of the mammals' roadkill included domestic animals. Omena Junior et al. (2012) found $16 \%$ of domestic mammals among mammals' roadkill, Freitas (2009) raised a total of $47 \%$, Esperandio (2011) recorded $28 \%$ of domestic 
TABLE 4

Relative Importance Weight (RIW) and effect of the land use and land cover descriptor variables among all models, BR-050 highway, Uberlândia-Uberaba, Minas Gerais state, Brazil

\begin{tabular}{lcccc}
\multicolumn{1}{c}{ Variables } & \multicolumn{2}{c}{ Wild mammals } & \multicolumn{2}{c}{ Domestic mammals } \\
& RIW & Effect & RIW & Effect \\
Agriculture & 0.92 & + & 0.19 & - \\
D_fragment & 0.47 & - & 0.42 & + \\
D_river & 0.53 & - & 0.24 & + \\
D_urban & 0.87 & - & 0.19 & + \\
N_fragments & 0.04 & - & 0.23 & + \\
Natural & 0.10 & + & 0.21 & - \\
River_presence & 0.05 & + & 0.34 & - \\
S_fragment & 0.06 & - & 0.54 & + \\
Silviculture & 0.88 & + & 0.70 & - \\
\hline
\end{tabular}

mammals and Bagatini (2006) $52 \%$. These authors also found Canis familiaris and Felis catus as the most killed domestic animals (Bagatini, 2006; Freitas, 2009; Esperandio, 2011; Omena Junior et al., 2012). Freitas \& Barszcz (2015) analyzed news on the internet about wildlife vehicle accidents and concluded that $70 \%$ involved domestic animals. All of these studies highlight the importance of domestic mammals' roadkill, both because of their frequency, and because the group includes large animals, which leads to greater chances of serious accidents involving greater material and human losses.

Cerdocyon thous and Euphractus sexcinctus usually appears as the most killed species of wild mammals in Brazil (Dornas et al., 2012). Both species are common and adapted to living in disturbed environments, they are omnivorous and even eat dead animals on the road, the same being true for Conepatus semistriatus (Reis et al., 2010). The BR-050 highway presented a roadkill rate of 0.03 wild mammals $/ \mathrm{km} /$ day which is relevant when compared to other researchers performed in a Cerrado region, 0.01 (Cunha, Moreira, \& Silva, 2010; Carvalho, Bordignon, \& Shapiro, 2014), 0.02 (Braz \& França, 2016); 0.03 (Cáceres et al., 2012; Brum et al., 2018). Anyway, roadkill rates are underestimated and a correction index needs to be calculated in order to try to get more actual numbers (Santos, Carvalho, \& Mira, 2011; Teixeira, Coelho, Esperandio, \& Kindel, 2013).

The non overlapping of wild and domestic mammals' hotspots can be explained by landscape characteristics since the effect of each environmental variable was different for wild and domestic mammal roadkill. Wild mammals' roadkill hotspots were located near a river, other researchers concluded that the roadkill probability increases with proximity to a river (Bueno, Sousa, \& Freitas, 2015; Ascensão et al., 2017). On the other hand, there are also results showing an opposite effect of this variable, as for Cerdocyon thous (Freitas, Oliveira, Ciocheti, Vieira, \& Matos, 2015). Two different hypotheses can explain these results: 1) wild mammals have to move more when they are distant from rivers ending up being a roadkill victim; 2) wild mammals prefer to move close to a river increasing the roadkill probability near a river. Anyway, it seems that the response to river distance depends on the species. For domestic mammals, there were more roadkill hotspots far from rivers, probably because humans supply their necessity for water.

We found hotspots are near the urban perimeter, in these same sites a higher number of roadkill was observed for Myrmecophaga tridactyla (Ascensão et al., 2017) and Chrysocyon brachyurus (Freitas et al., 2015). This condition was the opposite of that observed for Dasypus novemcinctus and Tapirus terrestris (Ascensão et al., 2017). These results may indicate that species with a small home range will avoid urban areas and species with bigger home ranges overlap these areas increasing their probability of being killed inside an urban environment, however, this hypothesis needs investigation. Although from 17 domestic mammals' hotspots, six are within $10 \mathrm{~km}$ from the urban areas, this variable is not important in explaining domestic mammals' hotspots. Probably, other variables related to human presence will explain domestic mammal's hotspots better, like the distance to the nearest farm or to a human building. 
Wild mammal roadkill hotspots were associated with a higher cover of agriculture (Rezini, 2010; Santana, 2012) and silviculture. We can observe the contrary effect for domestic mammals. We believe that with the lack of natural areas, wild mammals have to use agriculture and silviculture areas to forage, reproduce and move. As these areas may have fewer food resources, they have to move more and consequently their chance of being killed is higher. Magioli et al. (2016) concluded that agricultural and fragmented landscapes still sustain high biodiversity and ecological functions. Lyra-Jorge, Ciocheti, \& Pivello (2008) showed that silviculture areas maintain a similar biodiversity of medium and large-sized mammals when compared to natural Cerrado areas, executing an important function in connecting patches of native vegetation.

Wild mammals roadkill hotspots are near natural fragments. Bueno et al. (2015) report a positive relationship between the roadkill probability of large, arboreal and volant mammals and herbaceous vegetation cover. Ascensãoo et al., (2017) found that areas dominated by Cerrado had a higher roadkill probability for Cerdocyon thous and Euphractus sexcinctus. For domestic mammals, roadkill hotspots are located far from a natural fragment and when small fragments are bigger, since these animals are dependent on human care.

We conclude that wild and domestic mammals' aggregations do not overlap, one factor that can explain this non overlapping is how landscape cover influences roadkill hotspot location with the effect of each variable being different between domestic and wild mammals. Models that explain wild mammals' hotspots location are great, but domestic models are not, this might indicate that other factors that were not considered in this research may help explain domestic mammals' hotspot location, as distance to the nearest farm, for example. On the other hand, this non overlapping can be a result of scavenging, domestic mammals can act as scavengers consuming wild mammals carcasses and being killed (Slater, 2002; Schwartz et al., 2018). Therefore, stretches that could be a wild mammal hotspot will not, because of scavenging action. Furthermore, these stretches could become a domestic mammal hotspot when these animals are killed. That is why more studies about scavenging in Tropical regions are necessary.

The necessity to mitigate domestic mammals' roadkill exists and it should focus on humans, since we are responsible for taking care of domestic fauna. We advise education campaigns aiming to raise awareness about how dangerous it is for human safety to abandon domestic fauna on roads. Still, animals need to be contained adequately in their breeding areas in order to prevent them from going to the road. Castration is also important to prevent street animals from procreating. Another action that could decrease domestic mammals' roadkill is a rescue program, people could call when they see an animal near the road and it would be rescued. Finally, in many Brazilian cities the act of abandoning an animal is a crime, so the government should monitor and punish people who do so.

For wild mammals, already existing bridges and culverts could be adapted with the installation of dry ledges facilitating the movement of small and meso-sized mammals (Glista et al., 2009; Grilo et al., 2010). The construction of wildlife passages in the stretches identified as hotspots will facilitate fauna movement and prevent roadkill. Wildlife passages need to be similar to the environment around them, so they cannot be dark and the animal needs to see the beginning and the end of the passage; the climate needs to be similar also, not too hot neither too cold; the presence of vegetation at structure entrances and around will increase its use; as low human disturbance. As passage size increases, the number and diversity of species able to cross it also increase, so larger crossing structures are preferable. Fencing is very important in order to promote crossing use and can help prevent access to roads. In a metaanalysis Rytwinski et al. (2016) highlight that the combination of fencing and crossing structures led to an $83 \%$ reduction in roadkill of large mammals. Sometimes, animals are able 
to jump or climb over the fence, and structures that allow them to come back are necessary, as earthen ramps, one-way fixed steel gates and natural objects (Grilo et al., 2010). Finally, mitigation measures need to pass through constant monitoring in order to improve later initiatives, studies like before-after-control-impact (BACI) are strongly recommended (Lesbarrères \& Fahrig, 2012).

Ethical statement: authors declare that they all agree with this publication and made significant contributions; that there is no conflict of interest of any kind; and that we followed all pertinent ethical and legal procedures and requirements. A signed document has been filed in the journal archives.

\section{ACKNOWLEDGMENTS}

C. F. Carvalho-Roel was supported with a scholarship from the Coordenação de Aperfeiçoamento de Pessoal de Nível Superior (CAPES) - Finance Code 001. We thank the Institute of Biology for providing our transport to collect the data.

\section{RESUMEN}

¿Se traslapan las agregaciones de atropellos de mamíferos silvestres y domésticos? Los animales domésticos están involucrados en una gran cantidad de accidentes de tránsito y representan un peligro para los humanos debido a su tamaño. A pesar de esto, pocos estudios consideran a los animales domésticos. Es por eso que evaluamos agregaciones de atropellos de mamíferos, con el fin de ubicarlas y determinar si los atropellos de los mamíferos silvestres y domésticos se traslapan. Además, investigamos la influencia del paisaje en la ubicación de las agregaciones. Este estudio se realizó en la carretera BR-050, un área del bioma Cerrado, en el sureste de Brasil. El muestreo se ejecutó entre abril 2012 y marzo 2013, en automóvil, a una velocidad promedio de $60 \mathrm{~km} / \mathrm{h}$, y dos observadores buscaron animales atropellados en la carretera. Encontramos 482 mamíferos atropellados, incluidos 260 (54\%) mamíferos silvestres, 164 (34\%) ejemplares domésticos y $58(12 \%)$ especímenes indeterminados. De las 21 especies de mamíferos registradas, cinco fueron de origen doméstico. La tasa de mortalidad de mamíferos silvestres fue de $0.033( \pm 0.018)$ individuos $/ \mathrm{km} /$ día y la de domésticos de $0.020( \pm 0.008)$. Detectamos agregaciones de atropellos para mamíferos silvestres y domésticos. Los "hotspots" de atropellos de mamíferos domésticos y silvestres no se traslapan. Las variables que tuvieron la mayor influencia positiva en la probabilidad de atropello de mamíferos silvestres fueron: cobertura de la agricultura y la silvicultura; mientras que distancia al río más cercano, al perímetro urbano y al fragmento natural tuvieron un efecto negativo. Para los mamíferos domésticos estas variables con un efecto positivo fueron: área del fragmento más pequeño y distancia al fragmento natural; en tanto que la cobertura de silvicultura tuvo un efecto negativo. El que no haya un traslape de los atropellos de mamíferos silvestres y domésticos se podría explicar por el efecto de cada variable en la determinación de los "hotspots" de atropellos, ya que su efecto es diferente para los mamíferos silvestres y domésticos. Por otro lado, el no traslape puede ser el resultado de los hábitos carroñeros de los mamíferos domésticos. Proponemos diferentes tipos de medidas de mitigación con el fin de reducir los atropellos de los mamíferos domésticos y salvajes.

Palabras clave: ecología de carreteras; colisión de vehículos con la vida silvestre; hotspots de atropellos, mortalidad en las carreteras; patrones espaciales; Cerrado; América del Sur.

\section{REFERENCES}

Araújo, G. M., \& Haridasan, M. (1997). Estrutura fitossociológica de duas matas mesófilas semidecíduas em Uberlândia, Triângulo Mineiro. Naturalia, 22, 115-129.

Araújo, G. M., Nunes, J. J., Rosa, A. G., \& Resende, E. J. (1997). Estrutura comunitária de vinte áreas de cerrado residuais no município de Uberlândia, MG. Daphne, 7(2), 7-14.

Ascensão, F., Desbiez, A. L. J., Medici, E. P., \& Bager, A. B. (2017). Spatial patterns of road mortality of medium-large mammals in Mato Grosso do Sul, Brazil. Wildlife Research, 44(2), 135-146. DOI: 10.1071/ WR16108

Bagatini, T. (2006). Evolução dos indices de atropelamento de vertebrados silvestres nas rodovias do entorno da Estação Ecológica Águas Emendadas, DF, Brasil, e eficácia de medidas mitigadoras (Masters thesis). Brasília University, Brazil. Retrieved from http:// repositorio.unb.br/handle/10482/2248? mode=full

Bager, A., Piedras, S. R. N. P., Martin, T. S., \& Hóbus, Q. (2007). Fauna selvagem e atropelamento - diagnóstico do conhecimento brasileiro. In A. Bager (Ed.), Áreas Protegidas Repensando as escalas de atuação (pp. 1-14). Porto Alegre, Brazil: Armazém Digital. Retrieved from http://cbee.ufla.br/portal/imgs/imagesCMS/publicacao/pdf/18.pdf

Braz, V. da S., \& França, F. G. R. (2016). Wild vertebrate roadkill in the Chapada dos Veadeiros National Park, 
Central Brazil. Biota Neotropica, 16(1), 1-11. DOI: 10.1590/1676-0611-BN-2014-0182

Brum, T. R., Santos-Filho, M., Canale, G. R., Ignácio, A. R. A., Brum, T. R., Santos-Filho, M., ... Ignácio, A. R. A. (2018). Effects of roads on the vertebrates diversity of the Indigenous Territory Paresi and its surrounding. Brazilian Journal of Biology, 78(1), 125-132. DOI:10.1590/1519-6984.08116

Bueno, C., Freitas, L. E., Coutinho, B. H., Oswaldo Cruz, J. H., \& Castro Júnior, E. de. (2012). Sazonalidade de atropelamentos e os padrões de movimentos em mamíferos na BR-040 (Rio de Janeiro-Juiz de Fora). In A. Bager (Ed.), Ecologia de Estradas: tendências e pesquisas (pp. 167-178). Lavras: Ed. UFLA.

Bueno, C., Sousa, C. O. M., \& Freitas, S. R. (2015). Habitat or matrix: which is more relevant to predict road-kill of vertebrates? Brazilian Journal of Biology, 75(4), 228-238. DOI: 10.1590/1519-6984.12614

Cáceres, N. C., Casella, J., \& Goulart, C. S. (2012). Variação espacial e sazonal de atropelamentos e mamíferos no bioma cerrado, rodovia BR 262, Sudoeste do Brasil. Mastozoología Neotropical, 19(1), 21-33. Retrieved from http://www.redalyc.org/ articulo.oa? id $=45723408003$

Calcagno, V. (2015). Package glmulti 1.0.7, Title Model selection and multimodel inference made easy. Retrieved from https://cran.r-project.org/web/packages/glmulti/glmulti.pdf

Carvalho, C. F., Iannini Custodio, A. E., \& Marçal Junior, O. (2015). Wild Vertebrates Roadkill Aggregations on the Br-050 Highway, State of Minas Gerais, Brazil. Bioscience Journal, 31(3), 951-959. DOI: 10.14393/BJ-v31n3a2015-27468

Carvalho, N. C. de, Bordignon, M. O., \& Shapiro, J. T. (2014). Fast and furious: a look at the death of animals on the highway MS-080, Southwestern Brazil. Iheringia. Série Zoologia, 104(1), 43-49.DOI: 10.1590/1678-4766201410414349

Centro Brasileiro de Ecologia de Estradas. (2017). Atropelômetro. Retrieved from http://cbee.ufla.br/portal/ atropelometro

Chongsuvivatwong, V. (2018). epiDisplay: Epidemiological Data Display Package. Retrieved from https:// cran.r-project.org/package=epiDisplay

Clevenger, A. P., Chruszcz, B., \& Gunson, K. E. (2003). Spatial patterns and factors influencing small vertebrate fauna road-kill aggregations. Biological Conservation, 109(1), 15-26. DOI: 10.1016/ S0006-3207(02)00127-1

Coelho, I. P., Kindel, A., \& Coelho, A. V. P. (2008). Roadkills of vertebrate species on two highways through the Atlantic Forest Biosphere Reserve, southern
Brazil. European Journal of Wildlife Research, 54(4), 689-699. DOI: 10.1007/s10344-008-0197-4

Coelho, A. V. P., Coelho, I. P., Kindel, A., \& Teixeira, F. Z. (2011). Siriema: Manual do usuário (v1.1). Rio Grande do Sul: Universidade Federal do Porto Alegre. Retrieved from http://www.ufrgs.br/siriema

Coffin, A. W. (2007). From roadkill to road ecology: A review of the ecological effects of roads. Journal of Transport Geography, 15(5), 396-406. DOI: 10.1016/j.jtrangeo.2006.11.006

Concessionária de rodovias Minas Gerais Goiás S/A. (2018). Tráfego Mensal - 2018. Retrieved from http:// www.mgorodovias.com.br/index.php/mgo-rodovias/ nossos-números/tráfego-mensal

Cunha, H. F. Da, Moreira, F. G. A., \& Silva, S. D. S. (2010). Roadkill of wild vertebrates along the GO-060 road between Goiânia and Iporá, Goiás State, Brazil. Acta Scientiarum. Biological Sciences, 32(3), 257-263. DOI: 10.4025 /actascibiolsci.v32i3.4752

Dornas, R. A. P., Kindel, A., Bager, A., \& Freitas, S. R. (2012). Avaliação da mortalidade de vertebrados em rodovias. In A. Bager (Ed.), Ecologia de Estradas: tendências e pesquisas (pp. 139-152). Lavras: Ed. UFLA.

Esperandio, I. B. (2011). Padrões espaciais de mortalidade de mamíferos silvestres e domésticos na rota do sol (Bachelor's dissertation). Federal University of Rio Grande do Sul, Brazil. Retrieved from https://www. lume.ufrgs.br/handle/10183/35348

Ferreira, C. M. M., Ribas, A. C. D. A., Casella, J., \& Mendes, S. L. (2014). Variação espacial de atropelamentos de mamíferos em área de restinga no estado do Espírito Santo, Brasil. Neotropical Biology and Conservation, 9(3), 125-133. DOI: 10.4013/ nbc.2014.93.02

Forman, R. T. T. (1998). Road ecology : A solution for the giant embracing us. Landscape Ecology, 13, iii-v.

Forman, R. T. T., \& Alexander, L. E. (1998). Roads and Their Major Ecological Effects. Annual Review of Ecology and Systematics, 29(1), 207-231. DOI: 10.1146/annurev.ecolsys.29.1.207

Freitas, C. H. de. (2009). Atropelamentos de verterados nas rodovias $M G-428$ e SP-334 com análise de fatores condicionantes e valoração econômica da fauna (Doctoral thesis). Paulista State University Júlio de Mesquita Filho, Brazil. Retrieved from https://repositorio.unesp.br/handle/11449/106548

Freitas, S. R. de, \& Barszcz, L. B. (2015). A perspectiva da mídia online sobre os acidentes entre veículos e animais em rodovias brasileiras: uma questão de segurança? Desenvolvimento e Meio Ambiente, 33, 261-276. DOI: 10.5380/dma.v33i0.36910 
Freitas, S. R., Oliveira, A. N., Ciocheti, G., Vieira, M. V., \& Matos, D. M. da S. (2015). How landscape features influence road-kill of three species of mammals in the Brazilian savanna? Oecologia Australis, 18, 35-45. DOI: 10.4257/oeco.2014.18.05.02

Glista, D. J., DeVault, T. L., \& DeWoody, J. A. (2009). A review of mitigation measures for reducing wildlife mortality on roadways. Landscape and Urban Planning, 91(1), 1-7. DOI: 10.1016/j. landurbplan.2008.11.001

Gonçalves, L. O., Alvares, D. J., Teixeira, F. Z., Schuck, G., Coelho, I. P., Esperandio, I. B., ... Kindel, A. (2018). Reptile road-kills in Southern Brazil: Composition, hot moments and hotspots. Science of the Total Environment, 615, 1438-1445. DOI: 10.1016/j. scitotenv.2017.09.053

Grilo, C., Bissonette, J. A., \& Cramer, P. C. (2010). Mitigation measures to reduce impacts on biodiversity. In S. R. Jones (Ed.), Highways: Construction, Management, and Maintenance (pp. 73-114). USA: Nova Science Publishers, Inc. Retrieved from http://digital. csic.es/handle/10261/42404

John, F., \& Weisberg, S. (2011). An $\{R\}$ Companion to Applied Regression. USA: SAGE Publications, Inc.

Laurance, W. F., Goosem, M., \& Laurance, S. G. W. (2009). Impacts of roads and linear clearings on tropical forests. Trends in Ecology \& Evolution, 24(12), 659-669. DOI: 10.1016/j.tree.2009.06.009

Lesbarrères, D., \& Fahrig, L. (2012). Measures to reduce population fragmentation by roads: what has worked and how do we know? Trends in Ecology \& Evolution, 27(7), 374-380. DOI: 10.1016/j. tree.2012.01.015

Lüdecke, D. (2018). sjstats: Statistical Functions for Regression Models. Retrieved from https://cran.rproject.org/package $=$ sjstats

Lyra-Jorge, C. M., Ciocheti, G., \& Pivello, V. R. (2008). Carnivore mammals in a fragmented landscape in northeast of São Paulo State, Brazil. Biodiversity and Conservation, 17, 1573-1580. DOI: 10.1007/ s10531-008-9366-8

Magioli, M., Maria, K., Micchi, P., Ferraz, D. B., Zulnara, E., Setz, F., ... Alves, H. (2016). Connectivity maintain mammal assemblages functional diversity within agricultural and fragmented landscapes. European Journal of Wildlife Research, 62(4), 431-446. DOI: 10.1007/s10344-016-1017-x

Malo, J. E., Suárez, F., \& Díez, A. (2004). Can we mitigate animal-vehicle accidents using predictive models? Journal of Applied Ecology, 41(4), 701-710. DOI: 10.1111/j.0021-8901.2004.00929.x

Ministério do Meio Ambiente. (2015). Mapeamento Do Uso e Cobertura Do Cerrado: Projeto TerraClass
Cerrado 2013. Retrieved from http://www.dpi.inpe. br/tccerrado/index.php?mais $=1$

Montgomery, D. C., \& Peck, E. A. (1992). Introduction to Linear Regression Analysis. New York: Wiley.

Omena Junior, R., Pantoja-Lima, J., Santos, A. L. W. Ribeiro, G. A. A., \& Aride, P. H. R. (2012). Characterization of the vertebrate fauna hit on roadway BR 174, Amazonas, Brazil. Revista Colombiana de Ciências Ambientais, 4(2), 291-307. Retrieved from https://revistas.unisucre.edu.co/index.php/recia/ article/view/211

R Core Team. (2018). R: A language and environment for statistical computing. Vienna, Austria: R Foundation for Statistical Computing.

Reis, N. R., Peracchi, A. L., Fragonezi, M. N., \& Rossaneis, B. K. (2010). Mamíferos do Brasil (First Edition). Londrina: Technical Books Ed.

Rezini, J. A. (2010). Atropelamentos de mamíferos em rodovias do leste dos estados do Paraná e Santa Catarina, Sul do Brasil (Masters thesis). Federal University of Paraná, Brazil. Retrieved from https:// acervodigital.ufpr.br/handle/1884/23940?show=full

Rosa, R., Lima, S. C., \& Assunção, W. L. (1991). Abordagem preliminar das condições climáticas de Uberlândia (MG). Sociedade e Natureza, 3(5-6), 91-108.

Rytwinski, T., Soanes, K., Jaeger, J. A. G., Fahrig, L., Findlay, C. S., Houlahan, J., ... Van Der Grift, E. A. (2016). How effective is road mitigation at reducing road-kill? A meta-analysis. PLoS ONE, 1-25. DOI: 10.1371/journal.pone.0166941

Santana, G. D. S. (2012). Fatores influentes sobre atropelamentos de vertebrados na região central do Rio Grande do Sul, Brasil. Neotropical Biology and Conservation, 7(1), 26-40. DOI: 10.4013/nbc.2012.71.05

Santos, S. M., Carvalho, F., \& Mira, A. (2011). How long do the dead survive on the road? Carcass persistence probability and implications for road-kill monitoring surveys. PloS One, 6(9), 1-12. DOI: 10.1371/journal. pone. 0025383

Santos, R. A. L., Ascensão, F., Ribeiro, M. L., Bager, A., Santos-Reis, M., \& Aguiar, L. M. S. (2017). Assessing the consistency of hotspot and hot-moment patterns of wildlife road mortality over time. Perspectives in Ecology and Conservation, 15(1), 56-60. DOI: 10.1016/j.pecon.2017.03.003

Schwartz, A. L. W., Williams, H. F., Chadwick, E., Thomas, R. J., \& Perkins, S. E. (2018). Roadkill scavenging behaviour in an urban environment. Journal of Urban Ecology, 4(1), 1-7. DOI: 10.1093/jue/juy006

Slater, F. M. (2002). An assessment of wildlife road casualties - The potential discrepancy between numbers 
counted and numbers killed. Web Ecology, 3, 33-42. DOI: $10.5194 /$ we-3-33-2002

Teixeira, F. Z., Coelho, A. V. P., Esperandio, I. B., \& Kindel, A. (2013). Vertebrate road mortality estimates: Effects of sampling methods and carcass removal. Biological Conservation, 157, 317-323. DOI: 10.1016/j.biocon.2012.09.006

Teixeira, F. Z., Coelho, I. P., Esperandio, I. B., Oliveira, N. R., Porto, F., Dornelles, S. S., ... Kindel, A. (2013). Are road-kill hotspots coincident among different vertebrate groups? Oecologia Australis, 17(1), 36-47. DOI: 10.4257/oeco.2013.1701.04

Trombulak, S. C., \& Frissell, C. A. (2000). Review of Ecological Effects of Roads on Terrestrial and Aquatic Communities. Conservation Biology, 14(1), 18-30.

Van der Ree, R., Smith, D. J., \& Grilo, C. (2015). The Ecological Effects of Linear Infrastructure and Traffic: Challenges and Opportunities of Rapid Global Growth. In R. van der Ree, D. J. Smith, \& C. Grilo (Ed.), Handbook of Road Ecology (pp. 1-9). UK: John Wiley \& Sons, Ltd. DOI: 10.1002/9781118568170.ch1 